The animal of Melampus parvulus (Nutt.) agrees with the above in all respects excepting its tentacles, which are shorter and more stout in proportion.

I will take this opportunity of correcting an error in the habitat of Melampus pusillus $(\mathrm{Gm}$.). It does not occur at the Sandwich Islands.

The above observations show that Dr. Gray's opinion, that the shells are not always a guide to the generic relations of the animal, is correct.

\title{
2. Additional Notes on the Land-Shells of the Seychelles
} Islands. By Geoffrey Nevild, C.M.Z.S.

The land-shells of the Seychelles are not only remarkably few in number, but are also, generally speaking, local. This probably arises from the nearly complete destruction at some period or another of the original flora; for at Mahé, and at most of the other islands we visited, it was only on the extreme summit of one of the highest passes in the former, and on the top of the mountain at Silhouette, that I could perceive anything like a peculiar or ancient flora. Praslin, it is true, has a vast number of the Coco-de-mer trees and many shrubs, some of which may possibly prove peculiar and of interest to the botanist; but vegetation seems to thrive little better under them than under the ordinary Cocoa-nut or Vacoa Palm. It seemed to me evident that the flora at Mahé must originally have been very different. Large fires have probably been the chief cause of the destruction; and the cutting down the timber, whether for firewood or to plant Cocoa-nuts, must also have had considerable effect, and have enabled the Pine-apple, Cinnamon, Bamboo, \&c., and even possibly some of the common Mauritian ferns (Gleichenia \&c.) to obtain a firm footing. These introduced plants now cover large tracts of country, killing all the more delicate indigenous flowers and ferns. The first mentioned, more especially, is abundant in most of the islands, and grows almost up to the tops of the highest mountains. Where the large timber has been thus destroyed, the water, almost as soon as it falls, forms for itself channels, and, running off from the soil, causes it in a short time to become dry and more or less arid. This is clearly perceptible both at Mauritius and Bourbon. In such situations there are no shells to be found, excepting, indeed, some two or three species, such as Achatina fulica \&c. By searching, however, where the trees have been recently cut down, one finds quantities of dead shells, evidently killed by want of moisture and by exposure to the tropical sun.

Out of the meagre list of the land-shells I found at the Seychelles, I believe a considerable number to have been introduced. It does not appear difficult to account for this when one considers that such has been the case with a large number of the commonest trees and 
plants, amongst the roots \&c. of which they could easily have been brought. I have always noticed that the species having the supposed widest ranges are principally found close to the coast, or near some town, where, generally, the chief part of the vegetation has been introduced. In these places one rarely finds a species which can confidently be pronounced to be indigenous, about the only exception that I have met with being Gibbus mauritianus, which abounds everywhere in the sugar plantations near Port Louis. The commonest shell in the Mascarene Islands, as well as at Mahé and Praslin, is Helix similaris, which I believe has been thus introduced into all of them, either from India or Ceylon. At the great abundance of most of these species one cannot be surprised when one considers the vast numbers now to be found of Achatina panthera at Mauritius, and Achatina fulica at Calcutta, both of which have been introduced within the memory of many of the present inhabitants of those places. The others, of course, on account of their small size, have not been noticed, and consequently their introduction cannot be so easily traced.

The following are species which I believe, from the localities in which I found them, to have been introduced into the Seychelles :Helix similaris, Ennea bicolor, Subulina clavulus, Carychium mauritianum, Acicula mauritiana, Succinea striata, and Achatina fulica.

I should draw a very different deduction from the apparent affinities of the Seychelles Pulmonata to that which my friend and companion Mr. E. Newton, in his admirable paper in 'The Ibis' of $186 \%$, arrived at from his careful study of the ornithology of these islands, where he states, "As regards the Ornis of the Seychelles, its Malagash tendency is evident." Now the land-shells seem to me to have far more affinity with the Indian fauna than with the Malagash or African. Perhaps it would be more correct to say that the Seychelles fauna forms an intermediate and connecting link between the two, rather approximating to the former than to the latter.

Five genera are common to the Indian region which are not found in the Malagash, viz. Streptaxis, Cyathopoma, Onchidium, Helicina, and Paludomus, the reverse being the case with only two, Tropidophora and Gibbus. The only other species known of Stylodonta, as restricted, is from the Philippines (S. cepoides, Lea). The species of Discus and Conulus are also common Indian forms.

The only land-shells I can find recorded from the Seychelles which I did not myself meet with, are Helix militaris, Pfr., probably a variety of Stylodonta unidentata, and Bulimus ornatus, Duf., probably the species of which I have seen two specimens in the fine local collection of Mr. Caldwell, of Mauritius ; and if the same, it is a very handsome distinct species of the section Leptomerus, and must be extremely rare.

\section{Helix (Dorcasia) similaris, Fér.}

From Mahé and Praslin, where it abounds, but always near cultivated land, and never at any considerable height. The shells are 
a smaller thinner variety than the ordinary Mascarene ones, very seldom having a brown band on the last whorl.

2. Helix (Conulus), n. sp.?

From Mahé, Félicité, and Silhouette. Rare ; amongst dead leaves, \&c., in damp places.

3. Helix (Discus) serratus, H. Ad., n. sp.

From Mahé, Praslin, and Silhouette. Uncommon; on the ground in moist places.

4. Helix (Discus), n. sp.

From Silhouette. Very rare.

\section{Helix (Stylodonta) unidentata, Chemn.}

From Mahé, Félicité, Silhouette, and Curieuse. On the ground, amongst decaying leaves of the ordinary Cocoa-nut tree, \&c. This species is not found at all at Praslin. The variety from the three latter localities, as given above, differs from the Mahé typical form in being thicker, more produced, with a strongly marked brown band round the last whorl, and in often being deformed. This species, even in its youngest stages, can be readily distinguished from Styl. studeriana, the spiral striæ on the first few whorls not being cancellated, as is the case with the latter species; it is also far more globose, \&c. \&c. The animal is a uniform brown, varying in shade; the foot underneath is greenish, and the tentacles a purplish grey.

\section{Helix (Stylodonta) studeriana, Fér.}

From Praslin only. This species is remarkable from its being restricted to one island, like the extraordinary tree the Coco-de-mer, on whose leaves and trunk it lives; unlike the preceding species, I never found any live specimens of it on the ground. There are two varieties, one a rich brown colour, the other a decided yellow. In shape it always appeared to be perfectly constant; and the reflexed outer lip is always white, whilst in Styl. unidentata it is violetalthough I procured one specimen of the latter in which it also was white.

\section{Streptaxis souleyetiana, Petit.}

From Mahé, Praslin, and Silhouette. In damp places, on the ground. Animal ash-colour, the posterior part greenish yellow, stained on the neck with mauve (varying in shade), foot (underneath) yellow, tentacles black.

\section{Ennea (Elma) nevilli, H. Ad., n. sp.}

From Mahé and Silhouette. Extremely rare at the first-mentioned locality, more plentiful at the latter; on the ground, amongst dead leaves \&c. 
9. Subulina mauritiana, Pfr.

From Mahé and Silhouette. Amongst the husks of Cocoa-nuts, under stones, \&c. This shell, as well as the following, belongs to a most perplexing group; though I have examined a great many specimens, from every place where I have been, I have been unable to come to any satisfactory conclusion concerning them. The present species I take to be the same as one from Mauritius, but which I did not find at Bourbon; it is, if not the same, very closely allied to the common S. gracilis, Hutt., of Ceylon and India, although I have never seen the latter at all approaching it in size; the striæ also are a shade stronger, and the last whorl is a little less rounded and more angular in the present species. It is rery variable in size, my largest specimen having ten whorls and being 16 mill. long, while usually they have eight whorls and are about 12-14 mill. in length.

\section{Subulina, n. sp.?}

From Mahé, Praslin, Silhouette, and Félicité. In the same localities as the preceding. Certainly distinct from S. clavulus and $S$. mauritiana, also from $S$. gracilis, being more nearly allied to S. clavulina, P. \& M., from which, however, it seems to constantly differ in several respects. This Seychelles species I also found at Bourbon and Mauritius; S. clavulina, on the other hand, only at Mauritius.

\section{Achatina fulica, Fér.}

From Mahé, Praslin, and (I believe) Silhouette. A smaller, thinner variety than the Mauritian type; never very far from cultivated land.

\section{Acicula mauritiana, H. Ad., n. sp.}

From Mahé. Rare; under stones \&c.

\section{Succinea ?striata, Kr.}

From Mahé, Praslin, Silhouette, and Félicité. Amongst decayed leaves \&c., on the ground. This is certainly the same as the Mascarene species.

\section{Gibbus moreleti, H. Ad., n. sp.}

From Silhouette. Extremely scarce; I only found one specimen, at a great height.

\section{EnNea bicolor, Hutt.}

From Mahé, near Port Victoria, in the cinnamon groves. After a very careful examination of a large number of specimens from Mauritius, Seychelles, Ceylon, and India, I am convinced they are all one and the same species, in which case Pfeiffer's E. ceylanica must become a synonym. I have examined the animals both at Mauritius and Ceylon, which are perfectly similar. The shell varies 
slightly as regards the convexity of the whorls, the striation, and the spiral angle; these varieties I possess from all the above localities, occurring in all instances with others of the typical form. If $E$. ceylanica is to remain as a good species, I have three or four others possessing equal, or greater, claims to be distinguished.

\section{Helicina —?}

From Mahé, Praslin, and Silhouette. Amongst decayed leaves \&c., on the ground. The shell varies somewhat in colour, sometimes being a bright red, at others an orange-yellow.

\section{Onchidium - ?}

From Mahé. Under stones \&c., in damp places; common.

\section{ONCHidium - ?}

From Praslin. On the stems and leaves of the "Coco-de-mer." The differences between this and the preceding species afford a curious parallel to those between Styl. unidentata and Styl. studeriana. In each instance the Praslin species are far more finely developed than their Mahé representatives: whilst the latter appear to live always on the ground, the former seem to prefer a different habitat. Sometimes one sees the sea-cocoanut-trees covered with shells, not only the two above mentioned, but also Bulimus fulvicans, Cyclostomus pulcher, and others. On the common cocoa-nut tree I never at any place found any shell except Bulimus fulvicans. This species differs from the preceding in being considerably larger, in not possessing the oblong blackish spots, but in being covered with regular, small, roughish pustules, of the same colour as the rest of the animal, which is extremely variable. I found black, brown, and pure-white varieties; the underneath part also, instead of being a pinkish chocolate colour, is darkish yellow (varying in shade, sometimes quite white).

\section{Cyclostomus (Tropidophora) pulcher, Gray.}

From Mahé, Praslin, and Silhouette. On the Coco-de-mer, shrubs, \&c. The shell varies in colour, but not, apparently, in form.

20. Сyathopoma blanfordi, H. Ad., n. sp.

From Mahé. Extremely rare; amongst decayed leaves \&c., on the ground, near a stream, rather high up.

\section{Carychium, n. sp.?}

From Praslin, near the Protestant church, at the foot of a common cocoa-nut tree. I unfortunately only found a single specimen, which I hardly like to describe as new, though it differs from $C$. mauritianum in very many respects.

22. Melampus lividus, Desh.

From Mahé and Praslin.

Proc. Zool. Soc.-1869, No. V. 
66 DR. J. S. BOWERBANK ON SILICEO-FIBROUS SPONGES. [Jan. 28,

23. Melampus fasciatus, Desh.

From the same islands as the preceding.

24. Melampus Caffer, Küst.

From Mahé.

25. Melampus bridgesii, Carp.

From Mahé. Under damp stones, close to the sea; extremely local, I only found it at one spot.

26. Plecotrema, n. sp.?

From Mahé. Under the stones of an old jetty at Port Victoria; rare.

27. Neritina gagates, Récl.

From Praslin. In a very small rapid stream, close to where one crosses to go to Curieuse; very local.

28. Melania (Melanoides) tuberculata, Müll.

From Mahé, Praslin, and Silhouette.

29. Pyrazus palustris, Linn.

From a creek at Mahé, near Port Victoria.

30. Paludomus ajanensis, Morl.

From a rapid stream, rather high up, at Mahé; rarely collected.

31. Paludomus, n. sp.?

From Silhouette. Very rare; in a small stream, very high up.

3. A Monograph of the Siliceo-fibrous Sponges.

By J. S. Bowerbank, LL.D., F.R.S., F.Z.S., \&c.-Part I.

$$
\text { (Plates III., IV., V., \& VI.) }
$$

In my observations on Dr. Gray's “ Notes on the Arrangement of Sponges," published in the 'Proceedings' of this Society for 1868 (pp. $124 \& 125$ ), I have stated my objection to his arrangement of the siliceo-fibrous sponges, several species of which he has named and described in the volumes of the 'Proceedings.' His descriptions are very brief, and are mainly dependent on the characters of external form and the peculiarities of their surface; but although describing them as sponges, he appears to be still in a state of uncertainty regarding their real nature. In his descriptions of his genera MacAndrewia and Myliusia (Proc. Zool. Soc. 1859, p. 437), throughout the whole of the paper, he expresses doubts of their spongeous nature, and inclines to the belief, in p. 440, that they, with Dactylocalyx, might "all prove to be a peculiar family of 


\section{$2 \mathrm{BHL}$ Biodiversity Heritage Library}

Nevill, Geoffrey. 1869. "Additional Notes on the Land-Shells of the Seychelles Islands." Proceedings of the Zoological Society of London 1869, 61-66. https://doi.org/10.1111/j.1469-7998.1869.tb07295.x.

View This Item Online: https://www.biodiversitylibrary.org/item/91102

DOI: https://doi.org/10.1111/j.1469-7998.1869.tb07295.x

Permalink: https://www.biodiversitylibrary.org/partpdf/73767

\section{Holding Institution}

Natural History Museum Library, London

\section{Sponsored by}

Natural History Museum Library, London

\section{Copyright \& Reuse}

Copyright Status: Public domain. The BHL considers that this work is no longer under copyright protection.

This document was created from content at the Biodiversity Heritage Library, the world's largest open access digital library for biodiversity literature and archives. Visit BHL at https://www.biodiversitylibrary.org. 